\title{
Identification of Small Cells in Fetal and Infant Adipose Tissue
}

\author{
MARJORIE DUNLOP, ${ }^{(9)}$ J. M. COURT, J. B. HOBBS, ${ }^{*}$ AND T. J. C. BOULTON \\ Department of Paediatrics, University of Melbourne, Royal Children's Hospital, and Department of Anatomical \\ Pathology, Royal Melbourne Hospital (J.B.H.), Melbourne, Australia
}

\begin{abstract}
Summary
In developing adipose tissue, cells of size less than $25 \mu \mathrm{m}$ may make a major contribution to adipose tissue cell populations. This study reports the separation, identification, and sizing of infant and foetal adipose tissue small cells. Subcutaneous adipose tissue was taken from the anterior abdominal wall of children aged 2 months and 22 months. Subcutaneous tissue was also obtained from a paraumbilical site in 4 fetuses of gestational age 16 weeks. Tissue samples were fixed in buffered osmium tetroxide solution containing collidine. Aliquots of cell preparations suspended in saline on microscope slides were viewed and separated using a dissecting microscope. A diameter distribution of particle size was obtained using at least $\mathbf{2 0 0}$ cells for each preparation. There was a substantial number of cells that were smaller than $20 \mu \mathrm{m}$. Their modal cell size was remarkably constant in fetuses and in 2-monthold and 22-month-old infants. Ultrastructural studies show that the tissue is composed of a relatively uniform population of cells within sparsely collagenous connective tissue. Although some of the cells show no intracytoplasmic aggregates of lipid material, others show variable amounts of lipid material which can occupy a very large part of the cell volume.
\end{abstract}

\section{Speculation}

Developing adipose tissue in the fetus and young infant contains small cells that may represent differentiated fat cells. The recognition of these cells may be important in any study of adipose tissue development during periods of cell replication.

In a previous study (1) we have shown the presence of small cells and cell particles in fetal and infant adipose tissue. In that study it was apparent that in developing adipose tissue, cells of size less than $25 \mu \mathrm{m}$ may make a major contribution to adipose tissue cell populations. It was suggested that the study of such cells may prove to be important in understanding the development of fat tissue.

Cells used in this and other previous studies have been obtained using one of the most widely used methods for cell separation and identification, osmium tetroxide fixation (4). This method employs a system of filters to eliminate debris resulting from connective tissue digestion with collidine. A disadvantage of this method in the study of developing adipose tissue arises from this need for size selection. After osmium fixation there is a loss of cells below the pore size of the filter employed. This study reports the separation, identification, and sizing of infant and fetal adipose tissue of small cells, which have been shown previously to contribute to the total cell content of adipose tissue in early life.

\section{MATERIALS AND METHODS}

\section{SOURCE OF TISSUE}

Subcutaneous adipose tissue was taken, at surgery, from the anterior abdominal wall of four children aged 2 months and two children aged 22 months. Both fat expressed as a percentage of body weight was calculated from skinfold caliper measurements at multiple sites (2) (Table 1). Subcutaneous tissue was also obtained from a paraumbilical site in four fetuses of gestational age 16 weeks. This tissue was dissected free of dermis and underlying muscle tissue.

\section{TISSUE PREPARATION FOR CELL SIZING}

Tissue samples were fixed in buffered osmium tetroxide solution containing collidine, as previously described (1). Cells were gently separated from the digested matrix by a sieving action using tightly woven polyester cloth (Estal polyester thread cloth, 67 threads $/ \mathrm{cm}$ ). A distribution of particle size in the cell suspension was determined using an electronic counter employing the sizing conditions reported previously (1). In addition, aliquots of 10 cell preparations suspended in saline on microscope slides were viewed and separated using a dissecting microscope. The suspensions

Table 1. Clinical and tissue data

\begin{tabular}{cccccc}
\hline Tissue & Sex & $\begin{array}{c}\text { Postnatal age, } \\
\text { months }\end{array}$ & $\begin{array}{c}\text { \% Body wt } \\
\text { as fat }\end{array}$ & $\begin{array}{c}\text { Diameter of particle } \\
\text { type B, } \mu \mathrm{m}\end{array}$ \\
\hline $\begin{array}{c}\text { Fetuses } \\
1-4\end{array}$ & & & & & \\
& $16^{1}$ & & $11.45,12.24, \quad 12.55$ \\
Infants & & & & 13.46 & \\
5 & $\mathrm{M}$ & 2 & 13.8 & 13.46 & \\
6 & $\mathrm{M}$ & $2^{2}$ & 22 & 13.44 & \\
7 & $\mathrm{~F}$ & 2 & 10 & 13.44 \\
8 & $\mathrm{~F}$ & 2 & 17.5 & 12.55 \\
9 & $\mathrm{M}$ & 22 & 17 & 13.76 \\
10 & $\mathrm{M}$ & 22 & 16.4 & 12.55 \\
\hline
\end{tabular}

${ }^{1}$ Weeks of gestation.

${ }^{2}$ Born at 30 weeks of gestation.

could be separated into three types of particles. A diameter distribution of particle size was obtained for each of the three types using at least 200 cells for each preparation. These preparations were from both fetal and infant sources (Table 1).

\section{TISSUE PREPARATION FOR ELECTRONMICROSCOPY}

After dissection fetal subcutaneous tissue was fixed in $4 \%$ glutaraldehyde in cacodylate buffer, pH 7.2 (5). The tissues were then transferred to buffered osmium fixative (3) for $1 \mathrm{hr}$ at $4^{\circ}$ then to uranyl acetate $\left(1 \%\right.$ in $\left.\mathrm{H}_{2} \mathrm{O}\right)$ for $\mathrm{l} \mathrm{hr}$ at bench temperature. The tissues were embedded in Durcupan (Fluka AG, Basel, Switzerland) after dehydration with acetones. Sections were cut on an LKB Microtome using glass knives. Subsequent staining of sections was performed with an alkaline lead solution (6).

\section{RESULTS AND DISCUSSION}

The three types of particles separated at dissecting microscopy could be characterized as follows: type A, fragmented debris of 


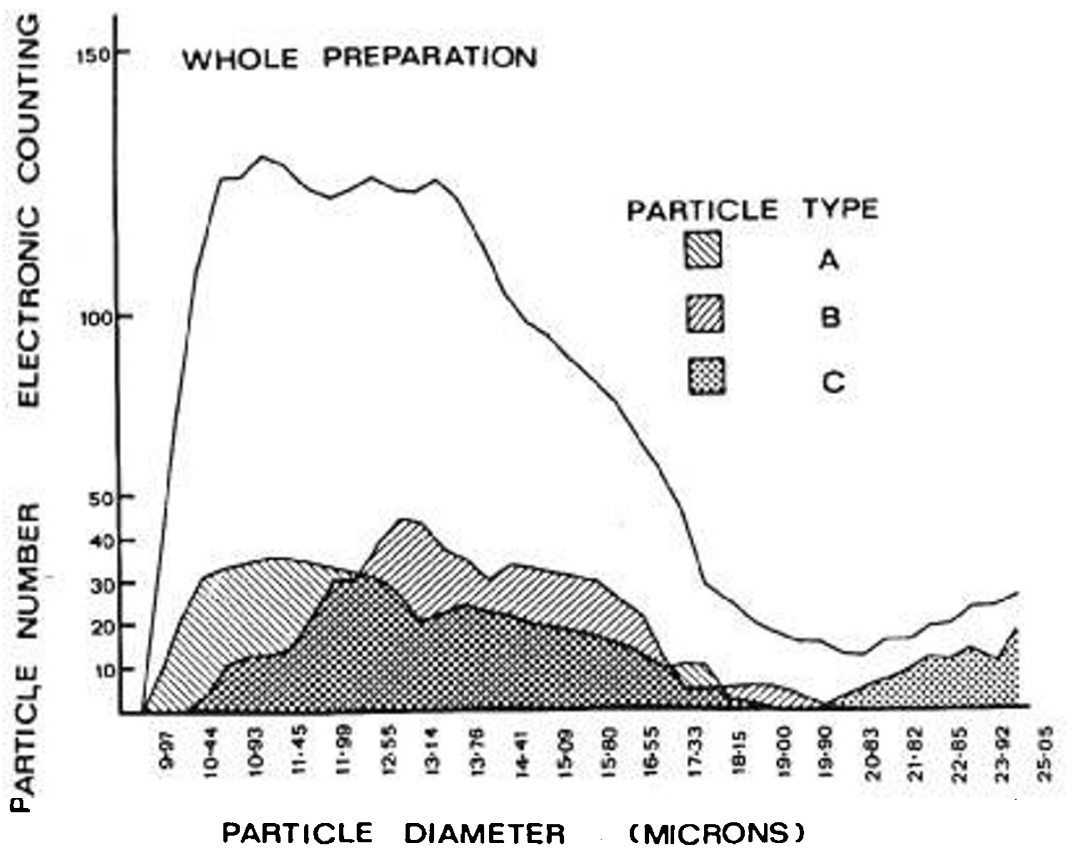

Fig. 1. Particle diameter distribution of cells less than $25 \mu \mathrm{m}$ from a representative sample of adipose tissue processed for cell sizing with the contributions of each subgroup. Type A, connective tissue debris and fragmented cells; type B, cells without osmium fixation on light microscopy; type $\mathrm{C}$, cells with full osmium fixation after dissection. Particle diameter is shown on a logarithmic scale.

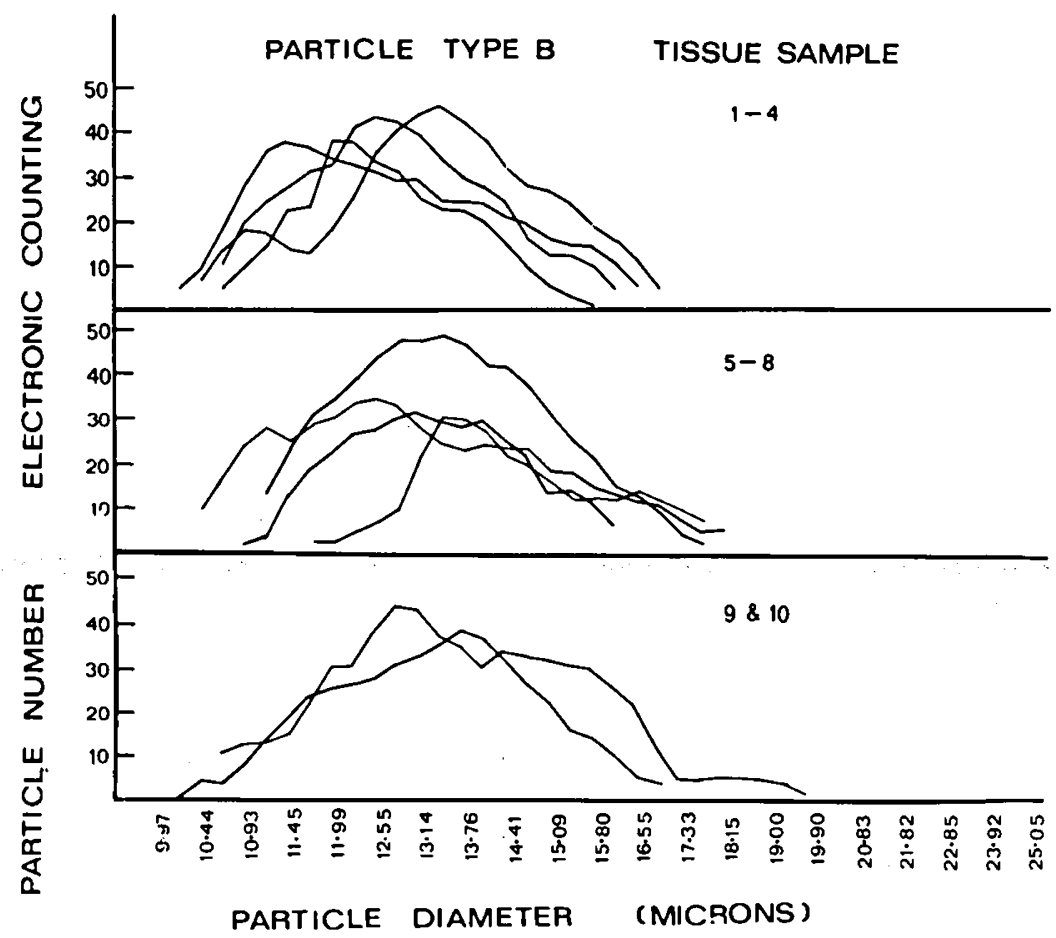

Fig. 2. Size distribution of cells without central osmium fixation (particle type B) from each adipose tissue preparation. Numbers refer to subjects described in Table 1.

cells and connective tissue; type B, intact cells which were not centrally fixed with osmium; type $C$, cells which had the generalized osmium deposition characteristic of mature adipose cells under these fixation conditions.
When the whole population of particles in a complete preparation was studied, there was a substantial number of cells found together with the debris that were smaller than $20 \mu \mathrm{m}$. This is less than the usually accepted lower limit of $25 \mu \mathrm{m}$ for fat cell identi- 


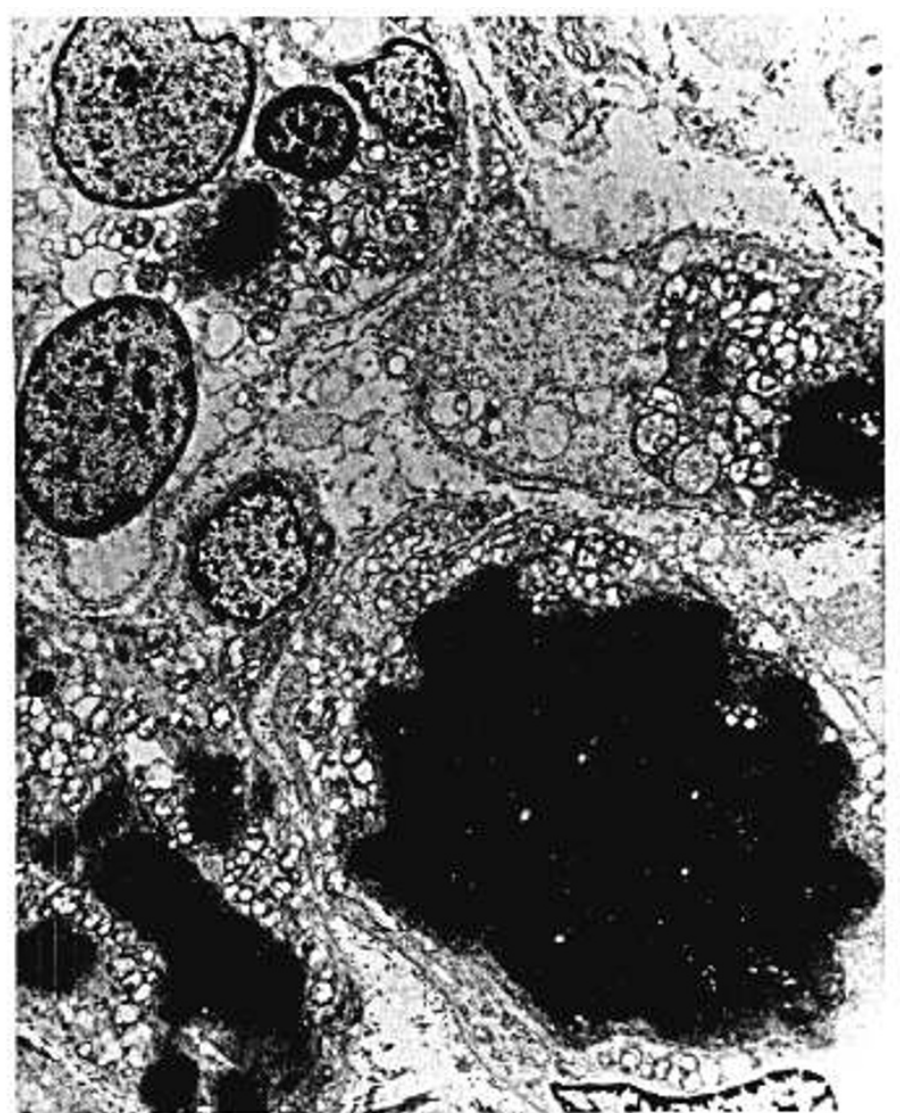

Fig. 3. Subcutaneous tissue from a 16- to 18-week human fetus. Cells with similar ultrastructural cytoplasmic structure show variable masses of quite intensely osmiophilic lipid material arranged in broad lobular masses $(\times 2400)$.

fication (4). Diameter distribution of the whole preparation suggested that small particles form a composite peak, but dissection showed the relative contributions of different particle types to this peak.

The particle distribution of a representative sample (subject 10) is shown in Figure 1, together with the individual size distribution of the three separated particle types from that preparation. Manual dissection as a means of separation of particle groups for sizing does not allow a quantitative measure of each of the groups' distribution to the whole population, but the type B particles, together with cell debris, formed the whole population of particles in the fetal tissue studied.

A review of particle type $B$ in each subject showed that their modal cell size was remarkably constant in fetuses and in 2 month-old and 22-month-old infants (Table 1 and Fig. 2).

When tissue from foetuses was examined by electron microscopy, ultrastructural studies show that the tissue is composed of a relatively uniform population of cells within sparsely collagenous connective tissue. The cells show very uniform nuclear characteristics and the cytoplasm is rich in mitochondria and polyribosomes. Some of the cells show no intracytoplasmic aggregates of lipid material but others show variable amounts of lipid material which can occupy a very large part of the cell volume (Figs. 3 and 4). Although the definition of the ultrastructure of the tissue shown in the electron micrographs has been affected by anoxic and osmotic changes occurring before tissue fixation was possible (4-5 hr postmortem), these studies suggest that in a relatively uniform population of cells within human fetal subcutaneous tissue there is a variable expression of lipid content.

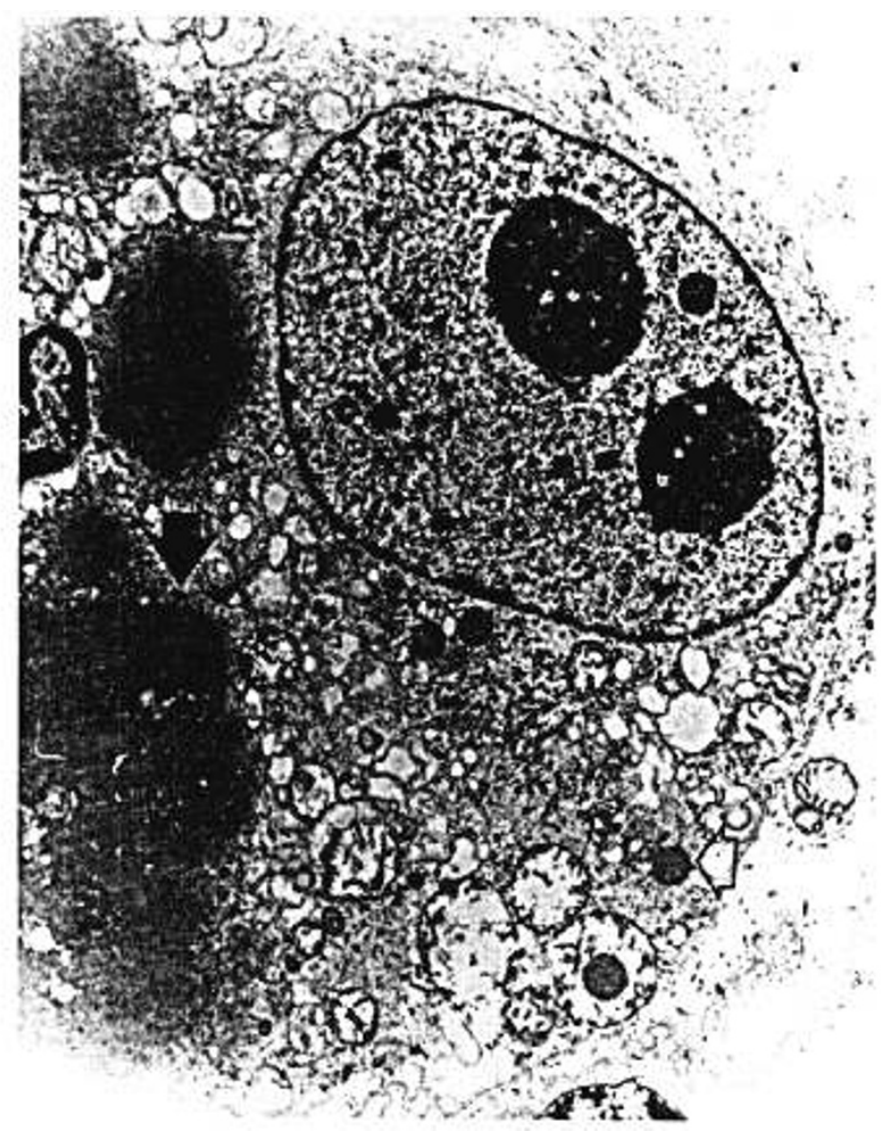

Fig. 4. Detail of relatively active cytoplasm with numerous mitochondria and polyribosomes in cells of fetal subcutaneous tissue. There are fine mildly osmiophilic vacuoles (open arrow) as well as the large and more intensely osmiophilic masses (closed arrow). Some mild artifactual variation is present in mitochondria due to delay in fixation $(\times 6000)$.

\section{CONCLUSION}

Small cells of diameter less than $20 \mu \mathrm{m}$ have been shown to be a substantial component of developing adipose tissue in human fetuses and infants. Electron microscopy has demonstrated early accumulation of fat in these cells. This suggests that they may represent differentiated adipose cells before they have accumulated sufficient triglyceride to allow them to be recognized by conventional techniques.

\section{REFERENCES AND NOTES}

1. Boulton, T. J. C., Dunlop, M., and Court, J. M.: The growth and development of fat cells in infancy. Pediat. Res., 12: 908 (1978).

2. Brook, C. G. D.: Evidence for a sensitive period in adipose cell replication in man. Lancet, ii: 625 (1972).

3. Caulfield, J. B.: Effects of varying the vehicle for $\mathrm{OSO}_{4}$ in tissue fixation. J. Biophys. Biochem. Cytol., 3: 827 (1957).

4. Hirsch, J., and Knittle, J. L.: Cellularity of obese and non-obese human adipose tissue. Fed. Proc., 29: 1516 (1970).

5. Sabatini, D. D., Bensch, K., and Barrett, R.: Cytochemistry and electron microscopy: The preservation of cellular ultrastructure and enzymic activity by aldehyde fixation. J. Cell Biol., 17: 19 (1963).

6. Venable, J. H., and Coggeshall, R.: A simplified lead citrate stain for use in electron microscopy. J. Cell Biol., 25: 407 (1965).

7. We thank Ms. Marie Robinson, Electron Microscopy Unit, Royal Melbourne Hospital for preparation of the electron micrographs.

8. Informed consent was obtained from parents of the infants included in this study

9. Requests for reprints should be addressed to: Dr. J. M. Court, Department of Paediatrics, University of Melbourne, Royal Children's Hospital, Parkville Victoria 3052 (Australia)

10. Received for publication March 28, 1977.

11. Accepted for publication December 12, 1977. 